\title{
Az animáció szerepe az elektronikus tankönyvekben
}

A tanulmány sokoldalúan szemlélteti az animáció fontosságát a számítógéppel támogatott tanításban és tanulásban. Szerzője elemzi a modern információs és kommunikációs technológiák segítségével multimediális formában feldolgozott és közvetített interaktív audiovizuális tananyagok által a tanulókra gyakorolt hatásokat. Az animáció nemcsak felkelti a tanuló érdeklődését és hosszabb ideig fenntartja a figyelmét, megrövidítve a prezentált információk megértéséhez szükséges időt, hanem hozzájárul a virtuális tanulási környezet kialakításához is. Az interaktív animáció azonnal szemlélteti a beavatkozások hatását és vizuális visszacsatolást ad azok eredményéről. A tanulmány áttekintést nyújt az animációk fajtáiról és osztályozásáról is.

Kulcsszavak: Elektronikus tananyag, animáció, interaktivitás, audiovizuális prezentáció, multimédia, információs és kommunikációs technológiák, virtuális tanulási környezet

Stoffa Veronika

\section{Szerzői információ:}

Informatikus, a Selye János Egyetem rektorhelyettese. 1974-ben szerzett mérnöki diplomát Pozsonyban a Szlovák Mû́szaki Egyetem Villamosmérnöki Karán a múszaki kibernetika irányzat számítástechnika szakán. Ezzel párhuzamosan megszerezte a pedagógiai minôsítést is. Az abszolvált egyetemen kezdte pályafutását mint tanársegéd, doktorandusz és késóbb adjunktus. 1981 és 1987 között adjunktusként tevékenykedett Liptószentmiklóson a Katonai Fôiskola Irányító és Számítástechnikai Tanszékén. 1983-ban Brünnben a Katonai Akadémián került sor docensi kinevezésére múszaki kibernetika szakon. 1987-ben a Nyitrai Pedagógiai Kar Matematika, majd Informatika Tanszékén folytatta pedagógiai és tudományos munkásságát, ahol szakmai garantálásával egy új tanulmányi szak, a számítástechnika kezdhette meg sikeres múködését. 2000-ben habilitált a matematika tanításának módszertana szakon a Nyitrai Konstantin Filozófus Egyetemen. 2001-ben megvédte a professzori minôsítését. 2004 szeptemberétól a Selye János Egyetem tanára, tanszékvezetôje és rektorhelyettese. Külsố munkatársként a Trencséni Egyetemen, a Nyitrai Szlovák Mezôgazdasági Egyetemen, valamint az Olomouci Palacky Egyetemen is tevékenykedett. Publikációi magyar, szlovák és angol nyelven jelennek meg, fóleg az informatika, számítógéppel támogatott tanítás, modellezés, szimuláció és irányított animáció tárgykörében. Eddig 3 monográfiája, 5 egyetemi jegyzete, 2 tankönyve és több mint 150 cikke jelent meg. Munkáira több mint 150 hivatkozást regisztrál. Több nemzetközi és nemzeti tudományos konferencia meghívott elôadója. Több doktori iskola tagja és témavezetôje.

Így hivatkozzon erre a cikkre:

Stoffa Veronika. „Az animáció szerepe az elektronikus tankönyvekben”. Információs Társadalom VIII, 3. szám (2008): 113-125.

$=$ https://dx.doi.org/10.22503/inftars.VIII.2008.3.7

A folyóiratban közölt müvek

a Creative Commons Nevezd meg! - Ne add el! - Így add tovább! 4.0

Nemzetközi Licenc feltételeinek megfelelően használhatók. 
Stoffa Veronika

\section{Az animáció szerepe \\ az elektronikus tankönyvekben}

\section{Bevezető}

Az információs társadalomnak több jellemző attribútuma van. Ezek közé sorolható a globalizáció, a decentralizáció, az elektronikus kommunikáció, a rekvalifikáció és a permanens vagy élethosszig tartó tanulás is, amelyben nagy jelentősége van az elektronikusan támogatott tanulásnak, az ún. e-learningnek.

A tudáson alapuló információs társadalomban az egész életen keresztül folytatott tanulás során jelentôs szerephez jutnak az elektronikusan feldolgozott és modern technológiákkal közvetített tananyagok. Az internet széles körú elérhetôsége, mindennapi hozzáférhetôsége és modern multimediális információhordozóként és információforrásként egyaránt, érvényesülő gazdag lehetôségei univerzális tananyag-prezentáló eszközzé tették az információs világhálót. Sok egyetem, iskola, intézmény, sốt még cég is külön szervert múködtet az elektronikusan támogatott tanuláshoz, helyet biztosítva elektronikus tankönyvek, segédeszközök, különbözố dokumentumok, elôírások, szabványok, dokumentumok elhelyezésére. A tanulást támogató elektronikus tankönyvek, tananyagok, segédanyagok, taneszközök leggyakrabban használatos keretrendszerét az ún. LMS (Learning Management Systems) nyújtja (Serafín 2002, Kočíková 2007, Kočíková-Štefková 2007).

\section{Elektronikus tanulás (e-learning)}

Az e-learning az elektronikus (elektronikus információforrásokkal támogatott) tanulás gyakran használt megnevezése. Magának a fogalommak a tartalma nincs teljesen tisztázva. Tág és igen nehezen körvonalazható kifejezéssel állunk szemben. Az elektronikus tanulás fogalmát megjelölő szó írásmódja sem egységes. A szakirodalomban e-learning, E-learning, e-Learning, elearnig, eLearning írásformájú szavakkal találkozhatunk. Gyakori az a jelenség is, hogy egy információforrás váltakozva használja a fogalmat jelölő szó különböző formáit, és sehol sem figyelmeztet arra, hogy ugyanarról van szó. Módszertani szempontból azonban helytelen ugyanazon fogalomra különbözó megjelöléseket használni.

Az angolszász irodalomban fóleg az eLearning forma használatos, mi ennek ellenére az e-learning írásmód mellett maradunk, mivel az e- elốtag az elektronikus jelzốt helyettesíti a rövidítésével, s így a magyar nyelvben is alkalmazható az e-alapú (elektronikus alapú) tanulás megjelölésére. Az e-learning (elektronikusan támogatott tanulás) elektronikus formában feldolgozott tananyagon alapul.

Az e-learning nem azonos a távoktatással (distance study), mert nem csak levelezốs formában valósítható meg. Nem azonosítható a számítógéppel támogatott tanulással (computer assisted learning, CAL) sem, mert megvalósítható számítógép nélkül is, pl. mo- 
biltelefon és különféle lejátszóberendezések felhasználásával is. Hasonlóképpen alakul a kapcsolat a webalapú tanulás és az e-learning között. Az 1. ábra grafikusan fejezi ki e négy fogalom kölcsönös kapcsolatait. A grafikus ábrázolásból is világos, hogy a közöttük létezó kapcsolatoknak nincs hierachikus jellege. Egyik sem foglalja magában a másikat, egyik sincs alá- vagy fölérendelve a másiknak. Kisebb vagy nagyobb részben fedik egymást (tehát vannak közös részeik), de vannak sajátos, egyedi, más halmazba nem besorolható komponenseik is.

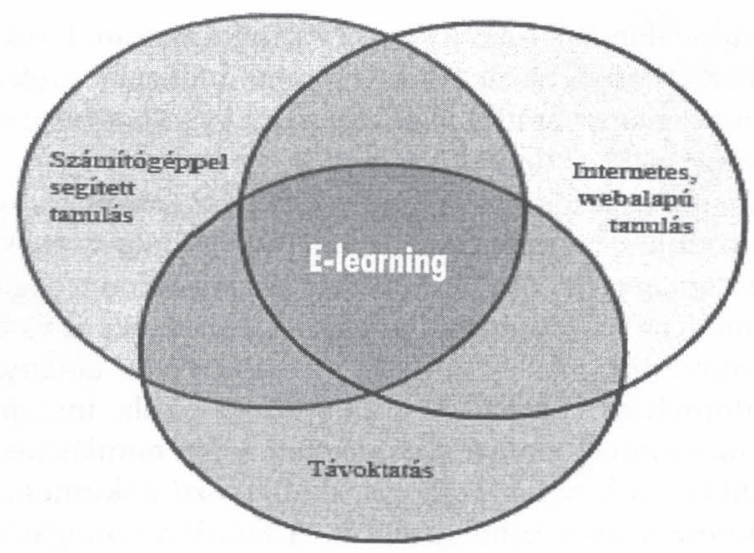

1. ábra

Az e-learning, a számítógéppel segitett tanulás, az internetes vagy webalapú tanulás és a távoktatás kapcsolatai

Annak ellenére, hogy a szakirodalom világosan megkülönbözteti a kombinált oktatás/tanulás (blended learning) fogalmát, az általános szóhasználatban azt is e-learningnek tekintik.

Az e-learningen széles értelemben minden elektronikus tanulási segédeszközzel támogatott tanulást értünk, leszúkített értelmezésben és szigorú elbírálás mellett azonban az e-learning fogalmán csak a webalapú keretrendszerrel menedzselt távoktatást/távtanulást értjük.

\section{Elektronikus tankönyvek}

Az „elektronikus tankönyv” megnevezést gyakran helytelenül alkalmazzuk bármilyen elektronikus szövegre, amelynek lineáris a szerkezete, esetleg fokozatosan felépített fejezetekre vagy témakörökre tagolódik. A feldolgozott tananyag sokszor a keretrendszerbe beépített kurzusok esetében is egyszerúen (esetleg fejezetekre bontva) pdf formátumú szövegfájlba van elmentve.

Az elektronikus tankönyv és tananyag a számítógéppel támogatott tanításban/tanulásban is helyet kaphat. A tanító fóleg magyarázata alátámasztására, a szemléletesség növelésére használja az elektronikusan feldolgozott tankönyvet. Ha az elektronikusan feldolgozott tananyag „tökéletes”, és helyettesíti a tanárt, akkor elég, ha a tanár megta- 
nítja a tanulókat az elektronikus segédeszköz kezelésére és az annak segítségével történó tanulásra (Chráska 2005, Chráska 2007). Egy PDF-formátumba konvertált, klasszikus tankönyvfejezeteket tartalmazó dokumentumot lineáris, esetenként hierarchikus szerkezetbe építve (a klasszikus tankönyv felépítését követve) csak nagyon nehezen lehet elektronikus tankönyvnek nevezni. Az ilyen „primitív” elektronikus segédeszköz nem használja ki a multimédiás számítógép lehetôségeit, s mondhatnánk, hogy ezekkel visszaél. Nem állíthatjuk azt, hogy a tankönyv elektronikus változata jobb, hiszen semmivel sem különbözik a klasszikus, nyomtatott formájától, legfeljebb talán annyiban más, hogy faszerkezetbe foglalva gyorsabb - esetleg teljesen ki is küszöbölhetố - a lapozás, amelyet navigációs elemekkel lehet helyettesíteni. Ehhez az elónyhöz azonban társulnak az elektronikustanulás-rendszer hátrányai: a tartalom megjelenítéséhez hardverre és szoftverre van szükség, a képernyôról való olvasás nagyobb mértékben terheli a szemet, mint a nyomtatott szöveg olvasása, illetve a nyomtatott gráfok, képek, illusztrációk tanulmányozása, a releváns információk kiválasztása (Kropáč 2004).

Elektronikus tankönyvnek leggyakrabban az olyan *.exe típusú fájlokat nevezzük, amelyek a szövegen kívül illusztrációkat, képeket, gráfokat, táblázatokat, hangot, zenét, animációt, navigáló- és irányítóelemeket is tartalmaznak. Az ilyen elektronikus dokumentum szerkezete már nem lineáris, hanem különböző jól átgondolt és a tudás rendszerezését is támogató struktúrákba van szervezve. Ez azt jelenti, hogy olyan információs alapegységekból tevődik össze, amelyek hivatkozásokkal (linkekkel) vannak nagyobb egységekbe kötve. A prezentációban az „információs egységeken” különbözố jellegú és különbözó szabályok alapján kódolt és rögzített információcsomagokat értünk. A szerkezetbe foglalt információk kezelésére és megjelenítésére, lejátszására átgondolt navigációs rendszer szolgál. A navigációs elemek az elektronikus tankönyvben sok esetben csak a gyors lapozás eszközéül szolgálnak (Lib 2005, Tulipán 2006).

Az elektronikus tankönyvet röviden a következóképpen definiálhatjuk: Az elektronikus tankönyv moduláris és dinamikus módon elektronikus formában feldolgozott tankönyv, amely egy adott témát (tantárgyat) megválas«tott terjedelemben és megválasะtott mélységig dolgow fel. A szaktudomány és terminológia szempontjából a szövege korrekt. A téma feldolgozásához multimédiával támogatott passzí és aktiv elemeket használ. A mondanivalót képekkel és animációkkal illusztrálva és hanggal kisérve mutatja be. A témát információs egységekre (items) bontva logikus, hipertext szerkezetü szerves egységgé formálja, amely támogatja az elsajátitott ismeretek rendszerezését. A beépitett online visszacsatolások és irányitóelemek aktí tanulásra serkentik a felhasználót, és egyben irányitják és optimalizálják az ismeretszerzési folyamatot, alkalmazkodva a tanuló tanulási stílusához és mentális szinvonalához.

Ennek a definíciónak ma leggyakrabban a világhálón elérhető „oldalak” formájában megszerkesztett és HTML nyelven megírt információkat, tudáselemeket tartalmazó prezentációk tesznek eleget. A hiperdokumentum-formátumban kódolt információk különféle megjelenítôprogramok (például Internet Explorer, Netscape Navigator, Mozilla stb.) segítségével hívhatók elő a képernyoón.

A multimediális prezentációhoz különféle speciális eszközökre (például hangkártyára, videokártyára, hangszóróra stb.) van szükség. Ahhoz, hogy valamely könyvból elektronikus tankönyv legyen, a tartalmát bizonyos pedagógiai mesterséggel hozzá kell igazítani a tanuló mentális képességeihez. Az elektronikus tankönyv szerkesztése és írása közben nagyon fontos betartani a didaktikai alapkövetelményeket, mert maga a könyv - 
beleértve a szerkezetét, formáját, kivitelezését, a beleépített irányító- elemeket, tanácsokat, a visszacsatolást stb. - a tanár szerepét is betölti (Stoffová-Kis-Tóth 1998).

Az elektronikus (és nem csak elektronikus) tankönyvek alapvetô vonásai közé tartozik, hogy a tartalmuk ismert tudásanyag, és meg van határozva, hogy kinek a számára és milyen céllal készülnek. 'Tartalmuk ehhez idomul, és a szerzô a „címzett” mentális színvonalát figyelembe véve, annak megfelelô formában tolmácsolja az információkat.

\section{Az elektronikus tankönyv tulajdonságai és jellemzői}

Az elektronikus tankönyv tulajdonságait és jellemzóit jelölhetnénk a „követelmények" megnevezéssel is. Fontos jellemzóje az elektronikus tankönyvnek a tudományos és szakmai jelleg, ami feltételezi a szerző tárgyi tudását. A helyes terminológia használata és a világos stílus szintén fontos követelmény. A szemléletesség növelésére az illusztrációk és képek mellett az elektronikus tankönyvben lehetôség van multimédia-jellegú elemek beépítésére is (Walat 2005).

Az elektronikus prezentációk dinamikus jellegét animációk segítségével tudjuk biztosítani. Az animációval szemléltetett szimulációs kísérletek szimulációs modelleken alapulhatnak. Az elektronikus tankönyv segítségével virtuális tanulási környezetet lehet kialakítani. A jól felépített hiperszerkezet megkönnyíti a tanulást, és elősegíti az új ismeretek rendszerezését (Feszterová 2007).

A multimediális kifejezés a modern elektronikus tankönyvek esetében az információk többféle formájára utal, amelyek ugyanazon a hordozón vannak tárolva, és megjelenítésük a multimediális számítógép vagy speciális lejátszóberendezések segítségével történik. Archiválásukra belsô és külsố memóriák (a merevlemezek és különféle információhordozók, például CD-k vagy DVD-k) szolgálnak, amelyek digitálisan rögzített szöveget, hangot, képet, mozgóképet és zenét is tartalmazhatnak.

A tananyag feldolgozása során a szerzó a modern és hatékony tanítási módszerek alkalmazása mellett figyelembe veheti az eltérő egyéni tanulási stílusokat is, mintegy „individualizálva" a tömeges tanítást. A rendszerbe foglalt elektronikus tankönyv használata közben nyomon követhetố a tanuló aktivitása, és lehetôség nyílik a tanulás menetének irányítására. A tananyag feldolgozásához rendelkezésre álló eszközök módot nyújtanak változatos tanulási környezet kialakítására és az egyes érzékszervek igénybevételének kiegyensúlyozására, például a szem védelmére hosszú szövegek olvasása helyett hangszekvenciák beiktatásával (Sík-Lányi 2001).

A tankönyv dinamikus strukturálása logikus hiperszerkezetek segítségével támogatja a tananyag rendszerezését az individuális tudásrendszer kiépítése érdekében. Lehetôség van más információforrások online használatára vagy ezeknek a prezentált anyagba való beépítésére is.

Aktív ismeretszerzésen a különböző forrásokból szerzett információk konfrontálását és értékelését értjük, ami kritikus gondolkodást követel a felhasználótól, és az új ismeretek egységbe foglalását támogatja. Az elektronikus tankönyv feldolgozását több fázisra bonthatjuk. Feltételezzük, hogy a téma és a címzett már ismeretes. Az elsố feladat az alapanyag (az információk, képek, gráfok stb.) összegyújtése, értékelése, kiválasztása és egyesítése. Ezt a fázist gyakran „tervezésnek” nevezzük. A második fázis az 
összegyứjtött anyag átdolgozása, egyesítése és transzformálása, a forgatókönyo megírása. Ez magában foglalja nemcsak a tankönyv szövegének megírását, hanem a képeknek és gráfoknak a címzett számára érthetô, egységes formába való áttételét is.

A forgatókönyv tartalmazza az egyes oldalak szerkezetét, a navigációs elemek rendeltetését és az egyes információs egységek összekovácsolására szolgáló elemeket is. A harmadik fázis a megvalósitás fázisa. Ebben a fázisban ki kell választanunk az elektronikus tankönyv megvalósításához felhasználandó eszközöket. Ahhoz, hogy jó döntés szülessen, a tárgyi tudással rendelkezố szerkesztốnek bizonyos mértékig ismernie kell az egyes eszközök lehetőségeit és korlátait is. Optimális esetben ebben a fázisban csapatmunkára kerül sor: a technikai munkatársak és a pedagógusok szoros együttmúködésben dolgozzák ki a megvalósítás koncepcióját. Ezt a fázist sokszor több lépésre bontják fel. Ekkor készülnek el a hang- és videofelvételek, valamint az animációk is, amelyek késóbb egy kompakt egységbe integrálódnak. A megvalósítás fázisa gyakran iterációs jellegư: a „végtermék” többszöri átdolgozás eredményeként alakul ki.

A negyedik fázis a produktum tesztelése fiktí környezetben. A produktum kipróbálása arra szolgál, hogy kiszúrjük a hiányosságait, növeljük az alkalmazás biztonságát és korrigáljuk a tárgyi pontatlanságokat.

Ezután következik az ötödik fázis, a reális környezetben való alkalmazás. Minden elektronikus tankönyv tartalmaz visszacsatolási lehetôségeket a felhasználók oldaláról. A visszacsatolás eredménye szolgál alapul az utolsó fázishoz, amelyben a tananyag aktualizálása, átdolgozása, finomítása és korrigálása történik. Ez a fázis - a szoftverek életciklusaiból vett analógiával - karbantartás néven ismeretes. Az elektronikus tankönyvek felújítása, átdolgozása és aktualizálása jóval egyszerúbb feladat, mint a nyomtatott tankönyveké.

\section{Az animáció jelentősége az elektronikus tankönyvekben}

Az animáció leggyakrabban a szemléletesség fokát növeli az elektronikus tankönyvben. Felgyorsítja a megértés folyamatát és a dinamikus jelenségek helyes értelmezését. Az animációnak többféle célja lehet:

Az illusstratí animáció dinamikus kép formájában szemlélteti az információt és élénkebbé teszi az elektronikus prezentációt. Legtöbb esetben motivációs szerepet tölt be. Példa erre különbözô mozgóképek beiktatása a prezentációba, amelyek videoszekvenciával is helyettesíthetốk. Ebben az esetben sokszor olyan animációkról van szó, amelyek navigációs elemek segítségével kezelhetók. Ennek a lehetőségnek azonban nincs irányító jellege, mert az aktív elem (hivatkozás, hiperlink) az animációt csak indítja, megállítja, felgyorsítja vagy lelassítja.

Ilyen animációk vannak például az olvasókönyvekben, nyelvkönyvekben, mesekönyvekben stb., hogy dinamikusabbá, élénkebbé, színesebbé, érdekesebbé tegyék a tananyagot. A 2. ábrán egy gyermekeknek írt, animációval átszốtt nyelvkönyv két oldalát látjuk. Az ábrán látható képernyő́másolatok sajnos csak jelezni tudják az oldalakon található animációkat, amelyek nagy számban gazdagítják a könyvet (Líšková 2003). A nyitóoldalon az érdeklódést felkeltố animációk vannak elhelyezve, amelyek bemutatják a könyv szereplóinek jellegzetes tevékenységeit: a postás nyomja a pedált a kerékpárján, a boszorkány repked a seprújén, a mackó tornászik stb. A jobb oldali képen (a 
postás kerékpározik) a kép dinamikája szemlélteti a történtek „,folyamatos jelen idóbe” való besorolását. Így a tanuló különösebb magyarázat nélkül megérti, hogy mikor melyik igeidốt kell használni az angol nyelvben.
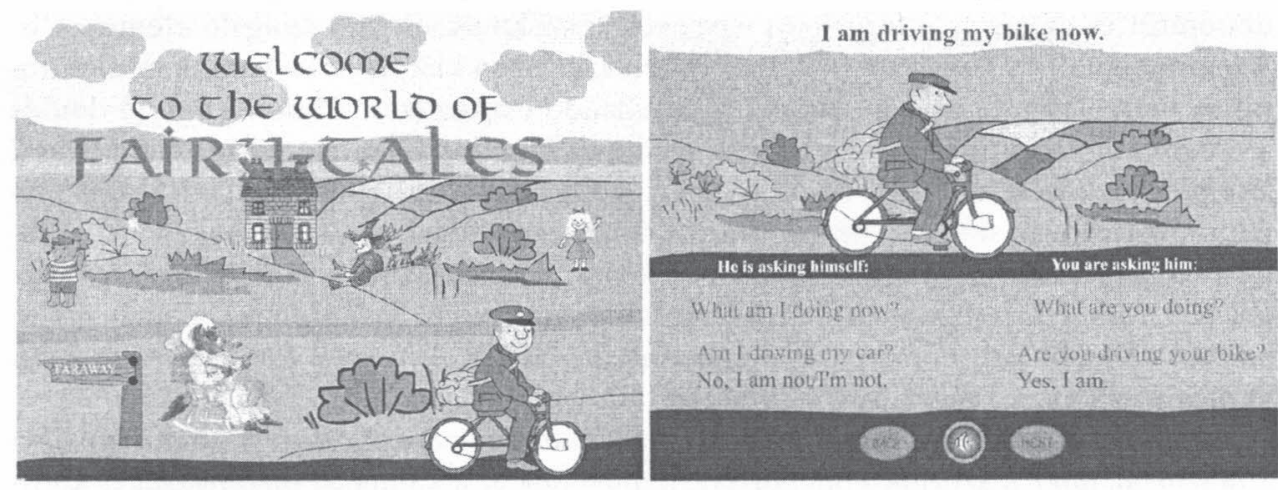

2. ábra

Animációval gazdagitott angol nyelvkönyv két oldala

Az animáció dinamikus jelenségek megértésére is szolgálhat. Megmagyarázza, milyen múködési elven alapul bizonyos jelenség. Sokszor találkozunk ilyen fajta animációval például az elektronikus fizikatankönyvekben. A 3. ábra bal oldali része az elektromos feszültség fogalmának magyarázatára szolgál. A jobb oldali kép azt illusztrálja, hogyan vezeti az elektromos áramot az elektrolitként múködő konyhasóoldat.

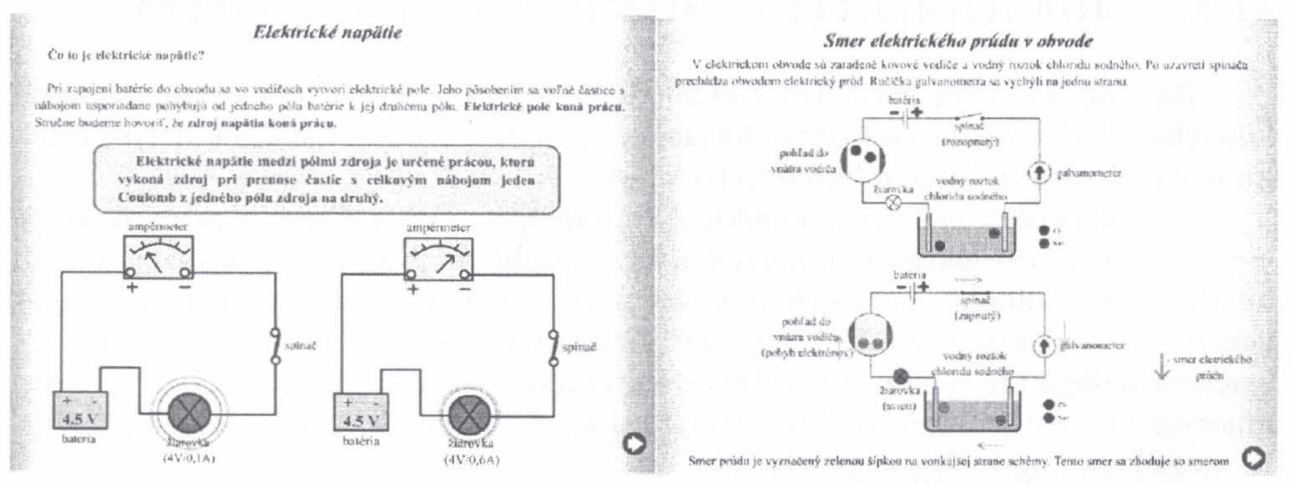

3. ábra

Animációval gazdagított szlovák elektronikus fizikatankönyv két oldala

Maga az animáció sok esetben egy gombra való rákattintással indítható, aktiválva valamilyen hivatkozást (hiperlinket). Ilyen megoldást választottak az optika tanításához készült elektronikus tankönyv szerzói, akik bőven iktattak be animációkat a tananyagba bizonyos jelenségek és alapelvek megértésének elősegítése céljából. 
A tankönyv szövegének olvasása közben a tanuló bármikor, akárhányszor elindít-

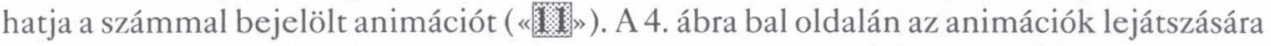
külön tér van kijelölve. Az ábrán ezen a területen a szemmel (az emberi látással) foglalkozó fejezet 11. számú animációja látható, amely a két szemmel megvalósuló térlátás múködési elvét szemlélteti. A tankönyvben a tananyag bóvítésére speciális jelölésú,

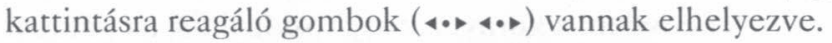

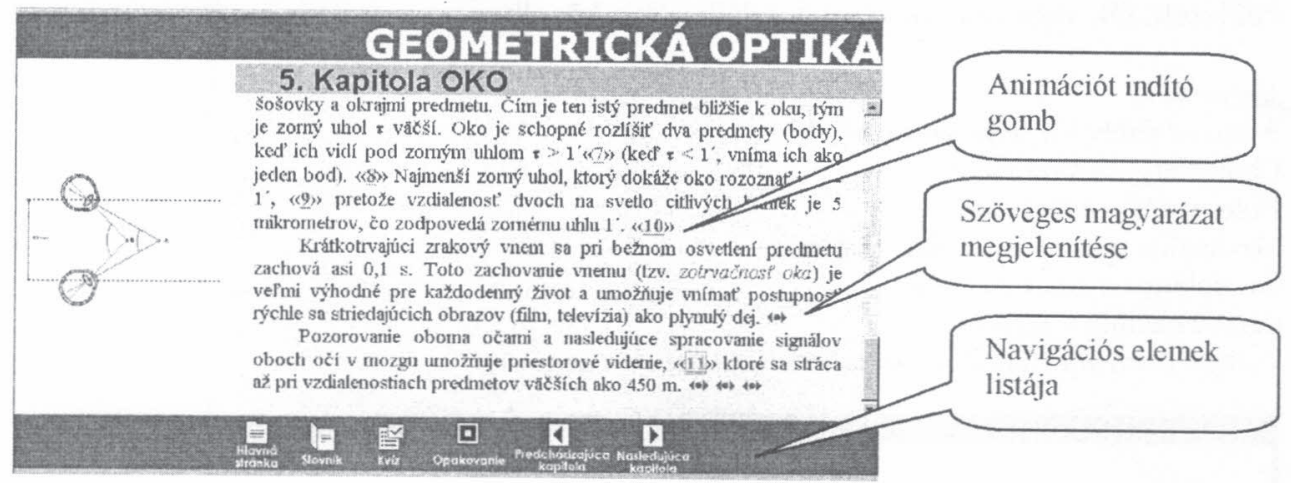

4. ábra

A szem (a látás) muikoödési elvének magyarázata animáció segitségével

Numerikus eredmények szemléltetése esetében gráfok, függvények dinamikus kirajzolásáról van szó. A kirajzolást irányítani lehet, ha a görbének van matematikai leírása: bármelyik paraméter megváltoztatásával azonnali hatást tudunk gyakorolni a kapott görbe formájára. Ez lehet például idófüggvény, dinamikus eseményt leíró differenciálegyenlet vagy egyenletrendszer megoldása stb. Az ilyen görbék megadhatók táblázatba foglalt mérési adatok értéktáblázatával is, ilyenkor a numerikus értékek alapján extrapolációs vagy interpolációs eljárások segítségével tudjuk levezetni a keresett függvényt. Az ábrázolás $2 \mathrm{D}$ vagy $3 \mathrm{D}$ számítógépes grafikai megoldásokon alapul: az idő függvényében alakuló görbe egyes diszkrét pontjait koordinátái segítségével ábrázoljuk. Derékszögú koordináta-rendszer használatakor a beépített matematikai modell alapján síkbeli (2D) ábrázolás esetében az egyes pontok $\mathrm{x}(\mathrm{t})$ és $\mathrm{y}(\mathrm{t})$, térbeli (3D) ábrázolás esetében pedig az $\mathrm{x}(\mathrm{t})$, y $(\mathrm{t})$ és $\mathrm{z}(\mathrm{t})$ koordináták értékét kell megadni. Ezeket a meghatározott (leggyakrabban szabályos) idóközökben $\left(t_{1}, t_{2}, \ldots t_{n}\right.$ idóben) a használt ábrázolás szabályai alapján kell megjeleníteni a képernyốn. Már az ilyen egyszerú grafikus ábrázolás esetében is alkalom nyílik bizonyos jelenségek és tulajdonságok elemzésére, amelynek alapján esetleg prognózisjellegú információkhoz is juthatunk.

Az 5. ábrán egy egyszerú képlet alapján számítjuk ki és ábrázoljuk a kilő́tt ágyúgolyó pályáját. A pálya alakját két megválasztható paraméter szabályozza: a golyó kezdősebessége és az ágyúcsốnek a talajjal bezárt szöge (a lövés iránya). A golyó útjának ábrázolásánál a vízszintes tengelyen az idő, a függóleges tengelyen pedig a golyó pozíciója (az adott időpontban elért magassága) szerepel. A képernyoómásolaton látható, hogy a beépített matematikai modell interaktív módon kezelhető, és egyszerú szimulációs kísérletek elvégzésére ad lehetốséget. A golyó magassága számértékben is megjeleníthetố bármely megválasztott idôpontban. Így tudjuk a fizikaórán szemléltetni a ferde hajítás elveit és fizikai szabályait. 
Ugyanezt meg lehet valósítani háromdimenziós térben is. Az ágyúgolyó pályájának idóbeli kirajzolásához ekkor azonban az $\mathrm{x}\left(\mathrm{t}_{\mathrm{i}}\right)$, $\mathrm{y}\left(\mathrm{t}_{\mathrm{i}}\right)$ és $\mathrm{z}\left(\mathrm{t}_{\mathrm{i}}\right)$ kifejezése szükséges a $\mathrm{t}_{1}$, $t_{2}, . . t_{n}$ diszkrét idôpontokban. Használhatunk pontosabb matematikai modellt is, amely számításba veszi például az idôjárás befolyását, a levegố közegellenállását, továbbá a golyó tömegét, méreteit és egyéb tényezóket is, amelyek befolyást gyakorolhatnak a golyó pályájára. Ugyanígy figyelembe lehet venni a környezet sajátosságait is, ha például épületek, fák vagy más akadályok találhatók a közelben.

\section{Magyarázat:}

Rýchlost' strely - a golyó sebessége

Uhol strely - a lövés szöge

Dolet strely - a lövés hossza

Maximálna výška - maximális magasság

Čas doletu - a földre érés ideje

Časový okamih - idôpont

Výška v časovom okamihu - az adott idốpontban elért magasság

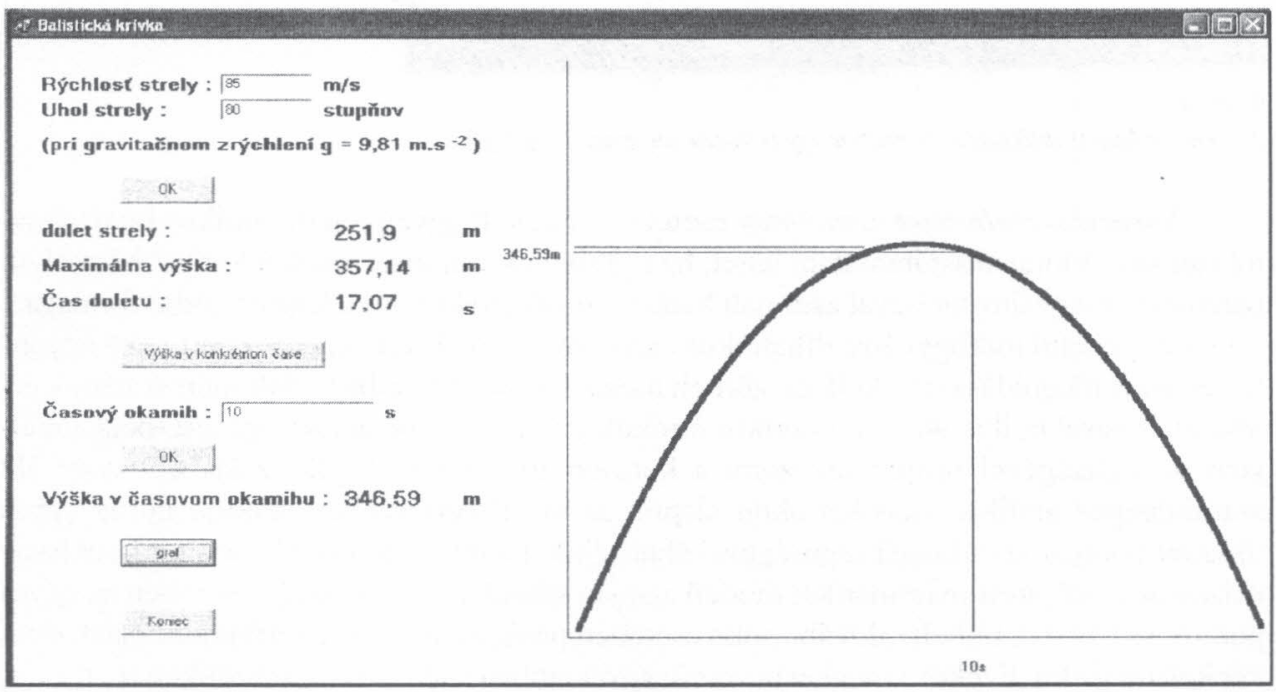

5 ábra

Az ágyúból kilött golyó uitvonala

Az irányított animációknak van egy különleges csoportja, amikor nem a matematikai modellból adódó numerikus eredményeket ábrázoljuk valamely függvény két- vagy háromdimenziós görbéjével, hanem maga a modellezett objektum, a reális világ része van ábrázolva vagy elképzelésünk alapján szemléltetve paraméterekkel irányítható grafikus ábrázolás révén. Ilyenkor a reális objektumot saját képével vagy prototípusával helyettesítjük, hasonlóképpen ahhoz, amikor a fizika tanítása során anyagi modelleket használunk például a négyütemú robbanómotor múködési elveinek bemutatására. A 6 . ábra a véletlenszerú események normális eloszlását a Galton-deszka segítségével mutatja be, nem a valószínúség számértékeivel, bár a lefelé haladó golyó útja ezek segítsé- 
gével is irányítható. A kísérlet folyamán a lefelé haladó golyó akadályhoz érve jobbra vagy balra egyaránt 0,5 valószínúséggel folytatja útját. Az egyes réseken való áthaladás valószínúségét a deszka geometriája alapján lehet levezetni. Például a jobb és bal oldali szélsố tartályokba a golyó $((((1: 2): 2): 2): 2): 2)=0,03125$ valószínúséggel jut el. A következó „célpontok” elérésének valószínúsége a deszka szélétól a közepe felé haladva növekedik, mert bizonyos rések elótt az útirányok valószínúségének összege van megadva. A második szint középsố résén a lefelé haladó golyó $0,25+0,25=0,5$ valószínúséggel halad át, tehát ezen a szinten az egyes rések használatának valószínúsége: $0,25+0,5+0,25=$ 1. Az egy szinten található rések valószínúségének összege mindig 1 , hiszen nem feltételezzük, hogy bármelyik golyó elakadhat, mindig mindegyik eljut valamelyik tartályba. A harmadik szinten a valószínúség értékei így alakulnak: $0,125+0,375+0,375+0,125=1$.

6. ábra

Galton-deszkával végzett kisérlet eredménye

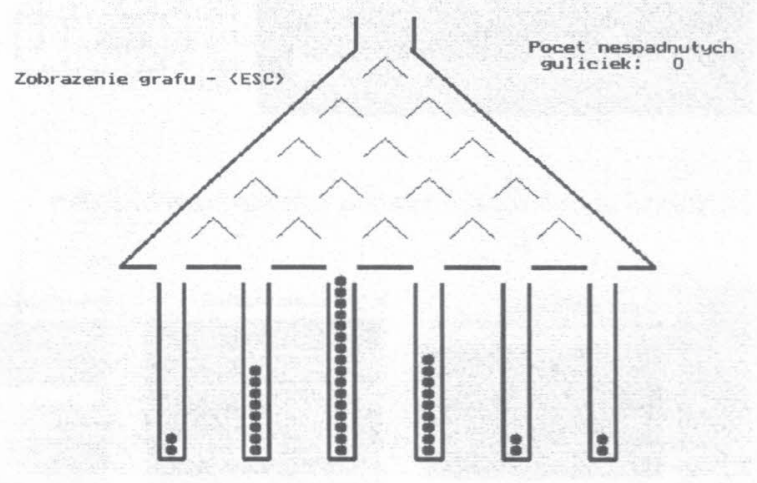

A két irányított animációtípus között nehéz különbséget tenni, hiszen az elóbbi esetben elég lett volna a golyót ábrázolni, amely voltaképpen röptében leírja a kijelölt utat, de konkrét idốben annak mindig csak egy diszkrét pontjában tartózkodik. Földet érése után már nem tudnánk értékelni, hogy milyen utat tett meg. A Galton-deszkán is a kísérlet eredményét látjuk, és nem tudjuk visszapörgetni a golyók útját (vagyis hogy milyen utat tettek meg, míg a tartályba kerültek), de akárhányszor megismételhetjük a kísérletet. A grafikus kivitelezés célszerú formáját mindig maga a forgatókönyvíró (vagyis a tanár) dönti el.

A használt modell sokszor interaktív editorként múködik. A következô példa egy animációval kísért, sztenderdizált dinamikus adatszerkezetek tulajdonságait és alapmúveleteit bemutató interaktív rendszer. Tartalmazza a vermet, a sort és az egy- és kétirányú láncolt listát. Szemléletesen bemutatja ezek felépítését, operációit és függvényeit (6. ábra). A felhasználó három kommunikációs nyelv (magyar, szlovák és angol) közül választhat. A rendszer büszkesége egy interaktív editor, amelynek a dinamikus adatszerkezetek kiépítésére és kezelésére szolgáló utasításokból álló eszköztára van. Ennek segítségével a felhasználó különböző utasítássorozatokat állíthat össze, amelyeknek a végrehajtását az alul elhelyezett „,vetítővásznon” tudja szemmel követni (7. ábra). Ha az eredmény különbözik az elvárttól, és nem felel meg, akkor visszaléphet. Így interaktív módon programot tud szerkeszteni, és értelmezni tudja az egyes utasításokat (StoffaVégh 2006, Végh 2006a, Végh 2006b). 
A fentiekben bemutatott animációs modellek vagy önálló alkalmazások, vagy elektronikus tankönyvek részei. A szerző a saját maga által kidolgozott alkalmazásokból vagy a vezetésével készült szakdolgozatok és diplomamunkák eredményeiból merített (Stoffa 1994, Stoffová 1995, Stoffa-Stoffa 2005).
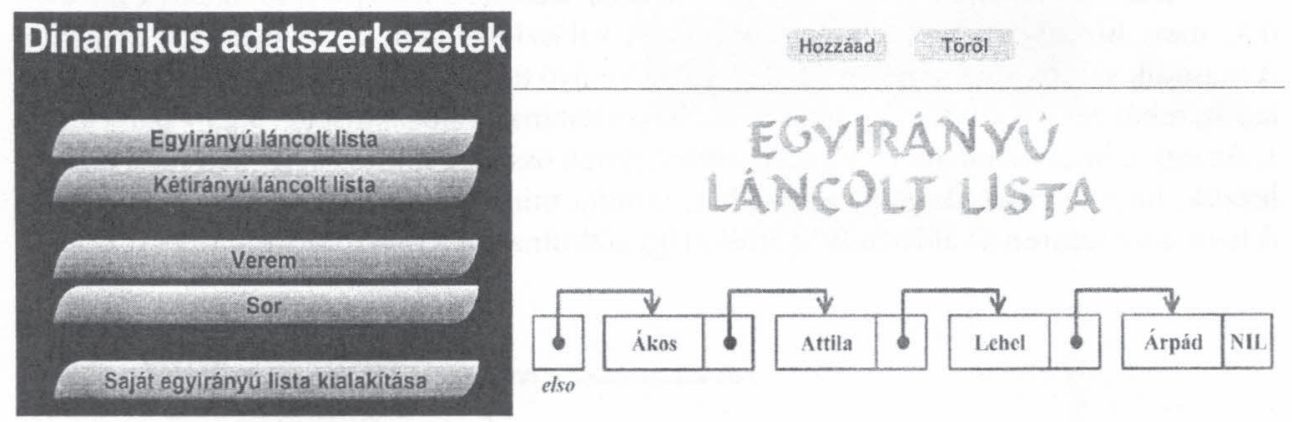

6. ábra

Egyirányú láncolt lista dinamikus adatsæerkezetek esetében

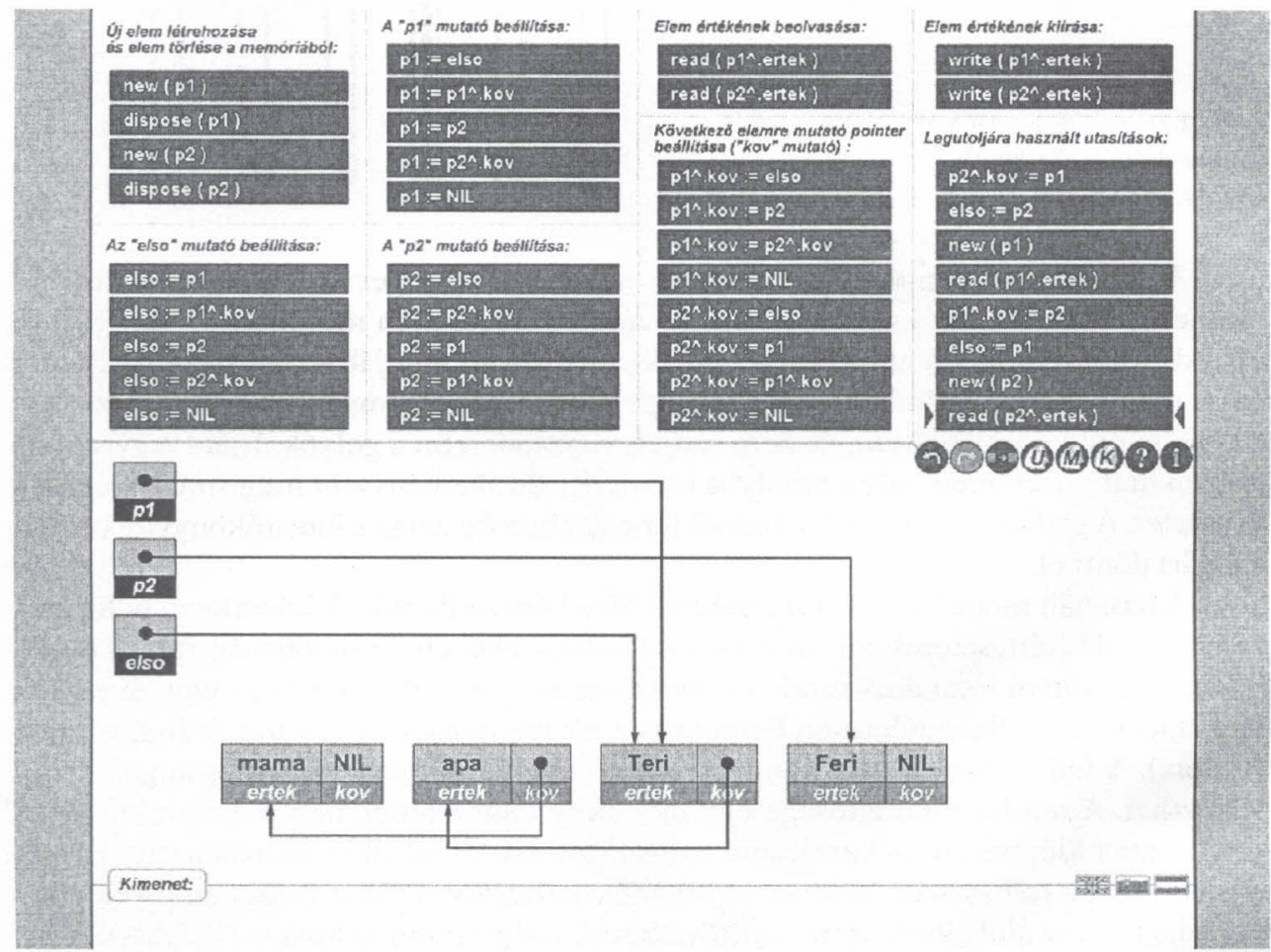

7 ábra

Dinamikus adatszerkezetek kialakitására és kezelésére szolgáló editor 


\section{Befejezés}

Az elektronikustankönyv-készítés teammunkát követel. Szükség van egyrészt tárgyi tudásra, pedagógiai, pszichológiai és módszertani ismeretekre, másrészt a megvalósításhoz felhasznált technológiai eszközrendszer ismeretére és annak kezelésében való jártasságra, szakmai tapasztalatokra. Mindezek a követelmények csak nagyon ritkán teljesülnek egyetlen szakember személyében, ezért a tanárok és a programozók szoros együttmúködésére van szükség. Maga az alkalmazott keretrendszer csak nagyon ritkán ad lehetóséget a tananyag szimulációs és animációs modellek segítségével történó prezentálására. Ezért sokszor más eszközt választ a programozó a forgatókönyvben található információs egységek kiépítésére, az elemi és a magasabb oktatási szinteken egyaránt. A gyakran választott eszközök közé tartozik például a Flash-környezet és a különféle mikrovilág-környezetek (Com Logo, Image, Game Maker) (Borsuková- Gabal’ová 2008, Gabalová 2008).

Az elektronikus tananyag feldolgozására érvényesek a Skinner által a programozott tanítás alapelveiként megfogalmazott elvek. Ezeket azonban a számítógéppel támogatott multimediális elektronikus tanítás és tanulás esetében az információs és kommunikációs technológiák lehetôségei alapján pontosítani és aktualizálni szükséges (Stoffová 2004).

- Az elektronikus tananyag kisebb információs egységekból épül fel, és így megfelelő mennyiségekben lehet adagolni.

- Egy bizonyos információs egység prezentálása után visszacsatolás következik, amely alapulhat begyakorláson, teszten vagy más felhasználói aktivitáson.

- Az információk tolmácsolása multimediális formában történik, hogy az információ befogadásában minél több érzékszerv vegyen részt.

- A tananyagnak támogatnia kell (sốt meg kell követelnie) a felhasználó aktív részvételét a tanulás folyamatában.

- Kölcsönös visszacsatolásról kell gondoskodni: nemcsak a felhasználó reagál a prezentációba beiktatott feladatokra, kérdésekre és utasításokra, hanem maga a rendszer is reagál a felhasználó válaszaira és beavatkozásaira.

- Ahol lehetốség nyílik rá, a tanulás/tanítás hatékonyságának növelése érdekében célszerú animációs és szimulációs modelleket beiktatni a tananyag prezentálásába.

- A modelleket úgy kell kivitelezni, hogy a felhasználó kísérletezhessen velük, és saját megfigyelései, tapasztalatai alapján jusson új tudás birtokába.

- A tanár (szerzó) pedagógiai tudása a tartalom, a szöveg, a képek, a gráfok és a modellek pedagógiailag megfelelő kialakításában nyilvánul meg.

- Az alkalmazásnak lehetốséget kell nyújtania a tanulás minden fázisának megvalósítására, beleértve a motiválást, az információk és ismeretek ötletes prezentálását, a begyakorlást és a tudás tesztelését is.

- Modern, aktuális és hatásos tanítási és tanulási eljárásokat kell beépíteni.

- Lehetốséget kell adni a konstruktív gondolkodási és problémamegoldási képességek kibontakozásának, az aktív tanulásnak és az együttmúködésnek.

- Fejleszteni kell a felhasználó kritikus gondolkozását, tanulási fegyelmét és a múveltségéért, tudásának színvonaláért való felelősségvállalását.

- A tanulásnak és múvelődésnek egész életen tartó szükségletté kell válnia. 
Az elektronikus tanulás és oktatás előtt nagy kihívások és nagy lehetôségek állnak. A szükséges múszaki eszközök már mindenki számára hozzáférhetốk. A távoktatás és az e-learning kutatásával foglalkozó szakemberek, tananyagfejlesztók, oktatástechnológusok felelőssége, hogy felhasználják ezeket a nagyszerú lehetőségeket a hatékonyabb oktatás megvalósítása érdekében. Így az érdekeltek minél gazdagabb kínálatból tudnak majd válogatni.

\section{Irodalom}

Borsuková, H. - Gabalová, V. 2008. Informatická gramotnost’ a jazyková kompetencia = nevyhnutnost'. XXVI. International colloquium on the Management of Educational Process: Proceeding of abstracts and electronic version of reviewed contributions on CD-ROM. Editori E. Hájková- R. Vémolová. Brno. Brno, University of Defence, Faculty of Economics and Management. ISBN 978-80-7231-511-6.

Chráska, M. jun., 2005. Informační výchova, informační technologie. In: Procházková, I. et al.: Technická výchova součást humanistického modelu pregraduální př́pravy učitelů. 1. vyd. Olomouc : Votobia Praha, s. 69-98. ISBN 80-7220-213-8.

Chráska, M., 2007. Měnící se role učitele a žáka v nastupující informační společnosti - výsledky výzkumu. In XX. DIDMATTECH, Díl II. Editori Ján Stoffa - Veronika Stoffová - Miroslav Chráska jun. 1. vyd. Olomouc, Votobia Olomouc, 458-463. ISBN 80-7220-296-0.

Feszterová, M. 2007. Príprava na laboratórne cvičenia s pomocou e-vzdelávania. XXV. mezinárodní kolokvium o řizeni osvojovacího procesu, zamiřené k aktuálním problémũ vědy, výchovy, vzdělávaní a rozvoje truirčiho myšleni. Sborník abstraktủ a elektronických verzí recenzovaných př́spěvkủ na CD-ROMu. Brno, Univerzita obrany, Fakulta ekonomiky a managementu, 51, ISBN 978-80-7231-228-3.

Gabalová, V. 2008. Mikrosvet - vhodný prostriedok na vyučovanie základov programovania In Huraj, L. (ed.): DIDINFO 2008. Banská Bystrica, Univerzita Mateja Bela, Fakulta prírodných vied. Abstract on 16., Contributions on CD-ROM ISBN 978-80-8083-556-9.

Lišková, K. 2003. Multimediálna učebnica angličtiny pre najmenších na CD-ROM (diplomová práca) Nitra, UKF - Fakulta prírodných vied, 48.

Kočíková, E. - Štefková, M. 2007. E-Learning Concept and Implementation at Universities, In: Informatics 2007: Proceeding of the Ninth International Conference on Informatics. - Bratislava, Slovak Society for Applied Cybernetics and Informatics. ISBN 978-80-969243-7-0 216-221.

Kočíková, E.: 2007. Analýza možností využitia LMS vo vzdelávacom procese. In Infotech 2007, Moderní informačni a komunimačni technologie ve vzděláváni. Olomouc, Pedagogická fakulta Univerzity Palackého, Moravská vysoká škola. ISBN 978-80-7220-301-7 -327-332.

Kropáč, J. et al. 2004. Didaktika technických prédmětů, vybrané kapitoly. 1. vyd. Olomouc, Univerzita Palackého v Olomouci, 224. ISBN 80-244-0848-1.

Lib, W. 2005. Projektowanie multimedialnych slowników technicznych zagadnenia podstawowe. Trendy technického vzdéláváni 2005. Editori Miroslav Chráska jun. a Jiří Kropáč. 1. vyd. Olomouc, Votobia Praha, 327-329.

Serafín, Č. 2002. Budoucnost technológií ve vzdělání. In Sborník příspevku: XX. Mezinárodní kolokvium o řrizeni osvojovaciho procesu. Vyškov, Vysoká vojenská škola pozemního vojska, 362-364. ISBN 80-7231-090-9.

Sík-Lányi C. 2001. Multimédiás oktatóprogramok tervezésének ergonómiai kérdései. In AGRIAMEDIA 2000. Eger, EKTF, 189-201. ISSN 1417-0868. 
Stoffa, V. 1994. Számitógépes modellezés és szimuláció az oktatásban. AGRIAMEDIA '94. Eger, ICEM-HUNDIDAC, 133-137.

Stoffa, V. - Stoffa, J.: 2005. Szimulációs és animációs modellek az elektronikusan tankönyvekben. In Agriamedia 2004. Eger EKTF, 419-427. ISBN 963-9417-09-2.

Stoffová, V. 2004. Počítač - univerzálny didaktický prostriedok. 1. vyd. Nitra, Univerzita Konštantína Filozofa, Fakulta prírodných vied, 172. ISBN 80-8050-450-4.

Stoffová, V. 1995. Simulation and animation models as didactic tools. EUROSIM '95, European Simulation Congress. Vienna, Technical University of Vienna, 1277-1280.

Stoffová, V. - Kis-Tóth, L. 1998. The Training of Expectant Teachers for Acquiring new Instructional and Informatic Technologies. In Technológia vzdelávania: Zväzok 1 Educational Technology, Volume 1. 1. vyd. Nitra, Slovdidac, 151-163.

Stoffová, V. - Végh, L. 2006. Guided animation of dynamic data structures. In Third Central European Multimedia and Virtual Reality Conference. Eger, 175-179. ISBN 963-9495-89-1.

Tulipán, J. 2006. Štruktúrované elektronické dokumenty v didaktickej prezentácii. XIX. DIDMATTECH 2006. Editori Ján Stoffa a Veronika Stoffová. 1. vyd. Komárno, Univerzita J. Selyeho, 2007, 153-157. ISBN 978-80-89234-23-3 (bibliografický odkaz č. 8 na s. 157)

Végh, L. 2006. Elektronická podpora vyučovania dynamických údajových štruktúr. XIX. DIDMATTECH 2006. Editori Ján Stoffa - Veronika Stoffová. 1. vyd. Komárno Univerzita J. Selyeho, 109-112. ISBN 978-80-89234-23-3 (citácia na s. 289, bibliografický odkaz č. 1 na s. 292).

Végh, L. 2006. Vizualizácia algoritmov vo vyučovaní programovania. In: Informatika v škole a v praxi. Ružomberok, Pedagogická fakulta Katolíckej univerzity v Ružomberku, 65-69. ISBN 80-8084-112-8.

Walat, W. 2005. Kuluturotworcze funkcje mediów w podręcznikach multimedialnych. Trendy technického vzdélávání 2005. Editori Miroslav Chráska jun. a Jiří Kropáč. 1. vyd. Olomouc, Votobia Praha, 410-413. 